\title{
Influence of containers, genotypes, fungicides and their combinations on seed rot in rice during storage
}

\author{
Rajbir Singh* and Karuna Vishunavat ${ }^{1}$
}

Department of Plant Pathology, Gochar Mahavidyalaya (P.G. College), Rampur Maniharan, Saharanpur (U.P.) India ${ }^{1}$ Department of Plant Pathology, G.B. Pant University of Agriculture and Technology, Pantnagar, U.S. Nagar (Uttrakhand) India

\section{ARITCLE INFO}

Received : 01.09 .2018

Revised : 21.02 .2019

Accepted : 02.03 .2019

\section{KEY WORDS :}

Containers, Genotypes, Fungicidal treatment, Seed rot, Hybrid rice,

Storage period

*Corresponding author:

Email : rajbirsingh2810@gmail.com

\begin{abstract}
The present investigation was undertaken to study the influence of containers (packaging material), genotypes and fungicides on per cent seed rot in rice during January to May in storage. In whole storage period seed rot incidence was recorded more in container cotton bags than in polythene bags. Minimum seed rot incidence was recorded in KMR-3, while maximum was recorded in CMS 58025 A. Seed treatment with fungicide Thiram reported minimum percentage of seed rot during all period of storage. As far as the cumulative influence is concerned, CMS 58025 A and CMS 58025 $\mathrm{B}$ in both containers (polythene bags and cotton bags) resulted more seed rot percentage, irrespective of all treatments of seed in comparison to other genotypes. Two fungicides i.e. Chlorothalonil and Contaf proved less effectiveness over rest of the treatments while Thiram treated seed showed minimum seed rot.
\end{abstract}

How to view point the article : Singh, Rajbir and Vishunavat, Karuna (2019). Influence of containers, genotypes, fungicides and their combinations on seed rot in rice during storage. Internat. J. Plant Protec., 12(1) : 10-14, DOI : 10.15740/HAS/IJPP/12.1/10-14, Copyright@ 2019: Hind Agri-Horticultural Society. 